\title{
PENGARUH KONSEP DIRI DAN KEMAMPUAN KOGNITIF SISWA TERHADAP MINAT PADA PELAJARAN BAHASA INGGRIS (SURVEY PADA SMK SWASTA KOTA TANGERANG)
}

\author{
Fitri Apriyanti \\ Universitas Bina Sarana Informatika, Jakarta \\ fitri.fap@bsi.ac.id
}

\begin{abstract}
Abstrak
Tujuan utama penelitian ini adalah mengetahui adanya pengaruh konsep diri dan kemampuan kognitif terhadap minat pada pelajaran Bahasa Inggris. Metode penelitian yang digunakan adalah metode survey korelasional, dengan jumlah sampel sebanyak 73 orang, yang diambil menggunakan teknik proportionate stratified random sampling. Instrumen yang digunakan adalah instrument pengisian angket dan tes hasil belajar. Dari hasil penelitian perhitungan analisis regresi diperoleh persamaan garis regresi $\mathrm{Y}=42,574+0,332 \mathrm{X}_{1}+0,359 \mathrm{X}_{2}$ dengan nilai signifikan 0,000 lebih kecil dari nilai $\alpha=0,05$ hal ini menunjukkan bahwa regresi berpola linear. Hasil penelitian menunjukkan 1) Terdapat pengaruh yang signifikan konsep diri dan kemampuan kognitif terhadap minat pada pelajaran Bahasa Inggris, siswa SMK swasta kota Tangerang, hal ini dibuktikan dengan perolehan nilai sig. $0,000<0,05$ dah $\mathrm{F}_{\mathrm{h}}=16,385$. Secara bersama-sama konsep diri dan kemampuan kognitif memberikan kontribusi sebesar 31,9\% terhadap variabel minat belajar Bahasa Inggris. 2) Terdapat pengaruh yang signifikan konsep diri terhadap minat belajar Bahasa Inggris, siswa SMK swasta kota Tangerang, hal ini dibuktikan dengan perolehan nilai sig. 0,004 $<0,05$ dah $t_{h}=2,986$. Variabel konsep diri memberikan kontribusi sebesar 14,33 $\%$ dalam meningkatkan minat belajar Bahasa Inggris. 3) Terdapat pengaruh yang signifikan konsep diri terhadap minat belajar Bahasa Inggris, siswa SMK swasta kota Tangerang, hal ini dibuktikan dengan perolehan nilai sig. 0,001 $<0,05$ dah $t_{h}=3,425$. Variabel konsep diri memberikan kontribusi sebesar 17,55 \% dalam meningkatkan minat belajar Bahasa Inggris.
\end{abstract}

Kata kunci: Konsep Diri, Kemampuan Kognitif, Minat Belajar, Bahasa Inggris

\section{PENDAHULUAN}

Bahasa Inggris merupakan suatu mata pelajaran penting di dalam sekolah. Bahasa Inggris diajarkan di sekolah mulai dari tingkat sekolah dasar sampai dengan sekolah menengah atas. Pelajaran Bahasa Inggris yang seharusnya menjadi pilihan utama bagi siswa ternyata tidak diminati banyak siswa.

Alasan terkemuka dari siswa menyebutkan bahwa pelajaran Bahasa Inggris sangat sulit, sehingga mereka kurang berminat untuk mendalaminya. Kecenderungan siswa ini diduga karena konsep diri yang dimilikinya. Siswa yang memiliki konsep diri yang baik akan dapat menyesuaikan dalam pembelajaran sehingga memiliki prestasi belajar yang baik, sebaliknya siswa dengan konsep diri tidak baik cenderung malas dan selalu mencari pembenaran dari kegagalan dalam berprestasi.

Konsep diri dapat diartikan sebagai keyakinan, pandangan, atau penilaian seseorang terhadap dirinya. Seseorang dikatakan mempunyai konsep diri tidak baik jika ia meyakini bahwa dirinya lemah, tidak berdaya, dan tidak dapat melakukan hal yang berguna. Sebaliknya seseorang dengan konsep diri yang baik akan terlihat lebih percaya diri dan selalu bersikap positif terhadap sesuatu, juga terhadap kegagalan yang dialaminya.

Pendidikan menengah kejuruan merupakan wadah yang melahirkan sumber daya manusia sebagai aset bangsa. Untuk itu aset suatu bangsa tidak hanya terletak pada sumber daya alam yang melimpah, tetapi terletak pada sumber daya alam yang berkualitas. Sumber daya alam yang berkualitas adalah sumber daya manusia, maka diperlukan peningkatan sumber daya manusia Indonesia sebagai kekayaan negara yang kekal dan sebagai investasi untuk mencapai kemajuan bangsa.

Pendidikan Sekolah Menengah Kejuruan (SMK) merupakan bagian dari sistem pendidikan nasional yang diselenggarakan sebagai lanjutan dari 
Sekolah Menengah Pertama (SMP) /Madrasah Tsanawisah (MTs): (1) Sesuai dengan bakat, minat, dan kemampuan dalam rangka memenuhi kebutuhan/kesempatan kerja yang sedang dan akan berkembang pada daerah tersebut. (2) Lulusan SMK merupakan tenaga terdidik, terlatih, dan terampil. (3) Mampu mengikuti pendidikan lanjutan dan atau menyesuaikan dengan perubahan teknologi. (4) Berdampak sebagai pendukung pertumbuhan industri (kecil atau besar). (5) Mengurangi angka pengangguran dan kriminalitas. (6) Pertumbuhan ekonomi dan pendapatan Negara melalui pajak penghasilan dan pertambahan nilai.

Tujuan umum, sebagai bagian dari sistem pendidikan menengah kejuruan SMK bertujuan: (1) menyiapkan peserta didik agar dapat menjalani kehidupan secara layak, (2) meningkatkan keimanan dan ketakwaan peserta didik, (3) menyiapkan peserta didik agar menjadi warga negara yang mandiri dan bertanggung jawab, (4) menyiapkan peserta didik agar memahami dan menghargai keanekaragaman budaya bangsa Indonesia, dan (5) menyiapkan peserta didik agar menerapkan dan memelihara hidup sehat, memiliki wawasan lingkungan, pengetahuan dan seni.

Tujuan khusus, SMK bertujuan : (1) menyiapkan peserta didik agar dapat bekerja, baik secara mandiri atau mengisi lapangan pekerjaan yang ada di dunia usaha dan industri sebagai tenaga kerja tingkat menengah, sesuai dengan bidang dan program keahlian yang diminati, (2) membekal ipeserta didik agar mampu memilih karir, ulet dan gigih dalam berkompetensi dan mampu mengembangkan sikap professional dalam bidang keahlian yang diminati, dan (3) membekali peserta didik dengan Ilmu Pengetahuan dan Teknologi (IPTEK) agar mampu mengembangkan diri sendiri melalui jenjang pendidikan yang lebih tinggi.

Kompetensi lulusan pendidikan kejuruan sebagai sub sistem dari sistem pendidikan nasional menurut Depdikbud (2001) adalah : (1) penghasil tamatan yang memiliki keterampilan dan penguasaan IPTEK dengan bidang dari tingkat keahlian yang sesuai dengan kebutuhan pembangunan, (2) penghasil tamatan yang memiliki kemampuan produktif, penghasil sendiri, mengubah status tamatan dari status beban menjadi asset bangsa yang mandiri, (3) penghasil penggerak perkembangan industri Indonesia yang kompetitif menghadapi pasar global, (4) penghasil tamatan dan sikap mental yang kuat untuk dapat mengembangkan dirinya secara berkelanjutan. Dikmenjur (2000) mengatakan bahwa hasil kerja pendidikan harus mampu menjadi pembeda dari segi unjuk kerja, produktifitas, dan kualitas hasil kerja dibandingkan dengan tenaga kerja tanpa pendidikan kejuruan.

Jadi pendidikan kejuruan adalah suatu lembaga yang melaksanakan proses pembelajaran keahlian tertentu beserta evaluasi berbasis kompetensi, yang mempersiapkan siswa menjadi tenaga kerja setingkat teknisi yang siap terjun memenuhi tuntutan dunia usaha dan dunia Industri (DU/DI).

Begitu pentingnya pembelajaran bahasa Inggris bagi siswa Sekolah Menengah Kejuruan (SMK) bertolak belakang dengan fenomena di sekolah. Pelajaran bahasa Inggris yang seharusnya menjadi pilihan utama bagi siswa ternyata sangat banyak siswa yang tidak berminat untuk mendalami bahasa Inggris. Hal ini terlihat dari banyak siswa yang malas di dalam proses belajar bahasa Inggris. Berbagai alasan terkemuka dari siswa yang menyebutkan pelajaran bahasa Inggris sangat sulit dipelajari sehingga mereka kurang berminat untuk mendalaminya.

Kemampuan kognitif yang dimiliki siswa tentunya akan mempengaruhi minat siswa terhadap mata pelajaran bahasa Inggris. Kecenderungan yang dimiliki siswa akan membawanya untuk memiliki minat yang tinggi atau rendah terhadap mata pelajaran ini. Perbedaan minat bukanlah tidak dapat di atasi tetapi diperlukan usaha yang sungguh-sungguh dari semua pihak yang terlibat, yaitu siswa dan guru.

Berdasarkan latar belakang tersebut di atas, penulis tergerak untuk melakukan penelitian mengenai Pengaruh kosep diri dan kemamuan kognitif siswa terhadap minat pada mata pelajaran bahasa Inggris sekolah menengah kejuruan (SMK). 
Arti minat menurut Slameto (2003: 180) merupakan suatu rasa lebih suka dan rasa keterikatan pada suatu hal atau aktivitas, tanpa ada yang menyuruh. Dengan kata lain, minat merupakan suatu rasa lebih senang dalam diri seseorang dalam memberikan perhatian yang lebih besar terhadap objek tertentu.

Menurut Hurlock (1981 : 420), minat merupakan sumber motivasi yang mendorong manusia untuk melakukan apa yang mereka ingin kerjakan di saat mereka bebas untuk memilih. Ketika manusia melihat sesuatu akan mendatangkan keuntungan atau manfaat berupa kepuasan dan kenikmatan, maka ketertarikan itu muncul. Ketertarikan itu akan memompa semangatnya untuk meraih kepuasan dan kenikmatan tersebut. Dengan demikian, setiap minat yang muncul akan memuaskan beberapa kebutuhan manusia baik berupa kepuasan atau pun kenikmatan itu sendiri. Semakin besar kebutuhan seseorang, maka semakin kuat dan kekallah minat orang tersebut. Demikian pula semakin sering minat diekspresikan dalam aktivitas seharihari, makin kuat pula minat tersebut.

Dari pendapat-pendapat di atas dapat disimpulkan bahwa minat merupakan suatu kekuatan yang memotivasi dan mendorong seseorang untuk cenderung memberikan perhatian yang lebih besar pada sesuatu.

Menurut Keraf dalam Smarapradhipa (2005: 1), memberikan dua pengertian bahasa,yaitu: Pengertian pertama menyatakan bahasa sebagai alat komunikasi antara anggota masyarakat berupa simbol bunyi yang dihasilkan oleh alat ucap manusia.Kedua bahasa adalah sistem komunikasi yang mempergunakan simbolsimbol vocal (bunyi ujaran) yang bersifat arbiter.

Dari definisi yang dikemukakan Keraf bahasa mempunyai peranan dalam berkomunikasi baik secara lisan maupun dengan symbol (tulisan). Lain halnya menurut Owen dalam Santoso (2001: 10) menjelaskan definisi bahasa yaitu, Language can be defined as socialy shared combinations of those symbols" (bahasa dapat didefinisikan sebagai kode yang diterima sosial atau sistem konvensional untuk menyampaikan konsep kegunaan simbol-simbol yang dikehendaki dan kombinasi simbol-simbol yang diatur oleh ketentuan). Dari definisi yang dikemukakan Owen tersebut, dapat dipahami bahwa bahasa adalah simbol atau kode dengan mengikuti ketentuan yang berlaku dalam masyarakat untuk menyampaikan konsep penulis kepada pembaca.

Menurut Santoso (2003:1), bahasa adalah, "Rangkaian bunyi yang dihasilkan oleh alat ucap manusia secara sadar." Dari definisi Santoso tersebut, dapat dipahami bahwa segala tutur kata secara sadar dengan membentuk rangkaian bunyi dari alat ucap manusia dapat dikatakan sebagai bahasa.

Menurut Wibowo (2001: 3), bahasa adalah "Sistem simbol bunyi yang bermakna dan berartikulasi (dihasilkan oleh alat ucap) yang bersfat arbitrer dan konvensional, yang dipakai sebagai alat komunikasi oleh sekelompok manusia untuk melahirkan perasaan dan pikiran." Pendapat tersebut menjelaskan bahasa digunakan sebagai alat berkomunikasi antar sekelompok manusia untuk menyampaikan ide dan pemikiran dari pembicara dengan kelompok lain (pendengar) dengan melahirkan kontak perasaan antara penutur dengan pendengar.

Dari uraian teori para pakar di atas dapat disimpulkan bahwa bahasa Inggris adalah tutur ucapan, baik secara lisan maupun tulisan (simbol), untuk mengutarakan, menyampikan dan melaporkan ide, pesan dan maksud kepada orang lain secara universal.

Uraian tentang minat pada bagian sebelumnya menjelaskan bahwa minat merupakan suatu kekuatan yang memotivasi dan mendorong seseorang untuk cenderung memberikan perhatian yang lebih besar pada sesuatu. Steward (2003 : v) mencoba menerapkan tujuan utama pengajaran kalkulus agar diminati oleh peserta didik melalui 3 aturan : "topik-topik harus disajikan secara geometri, numerik, dan aljabar". Ketiga aturan tersebut diperluas menjadi 4 aturan dengan menekankan sudut pandang verbal atau deskriptif.

Dari pendapat ahli di atas, dapat disimpulkan bahwa minat terhadap mata pelajaran bahasa Inggris merupakan kekuatan yang memotivasi dan mendorong siswa untuk cenderung memberikan 
perhatian yang lebih besar pada mata pelajaran bahasa Inggris meliputi adanya perasaan senang; ketekunan atau keseriusan; kebebasan memilih atas dasar kemampuan, keuntungan, dan manfaatnya; berusaha aktif meraih manfaat; serta memiliki kemampuan dan keterampilan dalam hal yang berkaitan dengan bahasa Inggris.

Dalam teori kepribadian, konsep diri merupakan hal yang sering dibahas serta dianggap besar pengaruhnya terhadap tingkah laku seseorang. Karena kosep diri adalah persepsi atau penilaian seseorang mengenai dirinya yang meliputi gambaran mengenai fisiknya, psikis, sosial dan prestasinya. Gambaran ini terbentk berdasarkan persepsi orang lain terhadap dirinya atau dapat juga berdasarkan internalisasi, pandangan dan penerimaan orang lain terhadap dirinya. (Gunarsah, 2003). Harry Stack Sullivan, seperti yang dikutip oleh Jalaluddin (2005: 16), menjelaskan jika kita diterima orang lain, dihormati, disenangi karena keadaan diri kita, kita akan cenderung bersikap menghormati dan menerima diri kita sebaliknya bila orang lain selalu meremehkan kita, menyalahkan kita dan menolak kita, kita akan cenderung tidak akan menyenangi diri kita. Nolte dan kawankawan (1983) mengemukakan beberapa teori yang diantaranya : (a) jika seseorang dibesarkan dengan dorongan, maka ia akan belajar percaya diri, (b) jika seseorang dibesarkan dengan dukungan maka ia akan belajar menyenangi dirinya, (c) jika seseorang dibesarkan dengan pujian, maka ia akan belajar menghargai, (d) jika seseorang dibesarkan dengan penghinaan maka ia akan belajar menyesali diri, (e) jika seseorang dibesarkan dengan cemoohan maka ia akan rendah diri.

Konsep diri yang dipunyai seseorang akan turut menentukan bagaimana ia menerima, merasakan dan merespon lingkungannya. Seseorang yang berpikir bahwa dirinya kurang baik maka ia menganggap remeh dirinya serta selalu membayangkan kegagalan disetiap usaha yang akan dilakukan, selanjutnya ia akan enggan untuk mencoba mengatasi kesulitan yang dihadapi. Tingkah laku tersebut menunjukkan keyakinannya bahwa orang tersebut tidak mempunyai kemampuan untuk melakukan suatu usaha dengan sebaik mungkin. Keyakinan tersebut mencerminkan sikap dan pandangan negative terhadap dirinya sendiri. Pandangan negatif terhadap dirinya menyebabkan individu mengharapkan tingkat keberhasilan yang akan dicapai hanya pada taraf yang rendah. Patokan rendah tersebut menyebabkan orang yang bersangkutan tidak mempunyai motivasi untuk mencapai prestasi yang gemilang. Sebaliknya seseorang yang menganggap dirinya positif, perbuatan akan dilakukan sungguh-sungguh, ia akan mau mencoba mengatasi kesulitan yang dihadapi, dengan demikian akan bertambah kemungkinannya untuk sukses. Jadi seseorang yang mempunyai konsep diri yang tinggi akan menunjukkan tingkah laku yang berbeda dengan orang yang mempunyai konsep diri yang rendah. Orang yang mempunyai konsep diri yang tinggi akan menunjukkan tingkat aspirasi yang tinggi, optimis, percaya diri, realistis, mandiri dan dapat menyesuaikan diri dengan baik.

Berdasarkan pendapat yang telah diuraikan di atas, maka dapat diambil suatu simpulan bahwa konsep diri adalah pandangan dan sikap individu terhadap kemampuan dirinya sendiri dan konsep diri mempunyai peran penting dalam menentukan dan mengarahkan seluruh tingkah laku individu. Peranan penting tersebut ditunjukkan dengan kenyataan bahwa setiap selalu berusaha untuk memperoleh keseimbangan dalam dirinya, selalu dihadapkan pada pengalaman hidup, dan selalu dipenuhi oleh kebutuhan untuk mencapai prestasi. Perbedaan keseimbangan antara pengalaman hidup dan kebutuhan untuk mencapai prestasi antara individu yang satu dengan individu yang lain, maka akan menyebabkan perbedaan tafsiran tentang dirinya sendiri.

Schermerhorn dkk mengatakan dalam bukunya yang berjudul Organizational Behavior bahwa "Cognitive ability, intelligence, social intelligence: Ability to gather, integrate, and interpret information; intelligence, understanding of social setting". Menurut Schermerhorn (2007 :307) "kemampuan kognitif, intelejensia, 
dan intelejensia sosial adalah kemampuan untuk mengumpulkan, menyatukan, dan mengintepretasikan informasi, dan pengertian kepada lingkup sosial." Dari definisi tersebut dapat kita simpulkan bahwa schermerhorn berpendapat bahwa kemampuan kognitif adalah kemampuan seseorang dalam hal mengumpulkan atau memperolah sebuah informasi. Lalu bagaimana orang tersebut menyatukan informasi itu dalam pemahamannya, setelah itu bagaimana orang tersebut mengintepretasikan atau mentransfer informasi tersebut kepada orang lain.

Sementara itu Hunter dalam Murphy (1999 ;184) memiliki definisi tentang kemampuan kognitif sebagai berikut: "General cognitive ability has been empirically related to performance on hundred of jobs".

Menurut Hunter dalam Murphy adalah bahwa kemampuan kognitif sangat berhubungan secara empirik dengan performa seseorang dalam mengerjakan banyak pekerjaan. Lebih lanjut Murphy (1999 :185) mengatakan bahwa: "In this article, the term ability refers to general factor that is associated with performance on all (or essentially all) tests that involve the active processing of information".

Dalam penjelasannya tersebut Murphy mengatakan bahwa kemampuan mengacu pada faktor-faktor umum yang berkaitan dengan performa keseluruhan atau bisa dibilang keseluruhan tes yang berkaitan dengan bagaimana seseorang memproses sebuah informasi.

Dari seluruh penjelasan Murphy dapat ditarik kesimpulan bahwa kemampuan kognitif adalah kemampuan seseorang dalam memproses satu atau lebih informasi, dimana proses dalam hal ini menyangkut juga mengenai pemahaman orang tersebut tehadap informasi yang dia dapatkan.

Dari berbagai konsep di atas maka penulis menyimpulkan bahwa kemampuan kognitif adalah kebisaan seseorang dalam melakukan berbagai macam tugas yang dibebankan pada khususnya mengenai pengumpulan informasi, pengintepretasian informasi, dan bagaimana transfer informasi tersebut kepada orang lain. Kemampuan kognitif menjadi sangat penting dalam hal pemecahan masalah, karna dalam pemecahan masalah tersebut maka seseorang yang kemampuan kognitifnya baik, dia akan dengan cepat menemukan inti masalah itu dan mengintepretasikan serta mencari jalan keluarnya.

Dengan demikian maka indikator yang dapat dibuat dari berbagai teori tersebut untuk mengukur kemampuan kognitif seseorang adalah sebagai berikut: (1) Orientasi social, (2) Kecenderungan memahami masalah, (3) Ketelitian dan kecermatan, dan (4) Kecenderungan terhadap pelajaran/pekerjaan.

\section{METODE}

Penelitian ini akan dilakukan di SMK Manggala yang beralamat di jalan Hos. Cokroaminoto Gg. Ilyas No. 63, Tangerang dan SMK Yadika yang beralamat di Jl. Raden Saleh No. 11, Karang Tengah.

Metode yang digunakan dalam penelitian ini adalah penelitian survei dengan analisis korelasional. Metode Survei yaitu penelitian yang mengambil sampel dari satu populasi dan menggunakan kuesioner sebagai alat pengumpul data yang pokok (Singarimbun. M. dan Sofian Effendi, 1995:3). Dimana data digunakan untuk menjelaskan hubungan kausal antara variabel-variabel melalui pengujian hipotesa.

Variabel penelitian terdiri dari variabel terikat (dependent variable) yaitu variabel keduanya sebagai minat siswa pada mata pelajaran bahasa Inggris (Y) dan dua variabel bebas (independent variable) yaitu konsep diri $\left(\mathrm{X}_{1}\right)$ dan kemampuan kognitif $\left(\mathrm{X}_{2}\right)$.

\section{HASIL DAN PEMBAHASAN}

\section{Data Minat belajar Bahasa Inggris (Y)}

Data minat belajar Bahasa Inggris diperoleh dari skor kuesioner 73 siswa yang menjadi sampel penelitian. Nilai yang di peroleh adalah terendah 82 , tertinggi 117 , rata-rata sebesar 102,26, median sebesar 102 , modus sebesar 102 dan simpangan baku sebesar 8,826.

\section{Data Konsep Diri Siswa $\left(\mathbf{X}_{1}\right)$}

Data konsep diri diperoleh dari kuisioner yang dijawab oleh 73 siswa 
dihasilkan skor terendah 81, skor tertinggi 116, skor rerata sebesar 97,58 median 96 , modus sebesar 96, dan simpangan baku sebesar 8,695.

\section{Data Kemampuan Kognitif $\left(\mathbf{X}_{2}\right)$}

Data kemampuan kognitif diperoleh dari nilai tes yang dijawab oleh 73 siswa sebagai responden dihasilkan nilai terendah 60 , nilai tertinggi 95 , nilai rerata sebesar 78,84 , median sebesar 80,00 , modus sebesar 75 dan simpangan baku sebesar 8,957.

\section{Uji Asumsi Klasik}

Uji Normalitas Data menunjukkan distribusi data pada analisis regresi ini mengikuti distribusi normal. Hal ini ditunjukkan dengan semua nilai Asymp. Sig $>0,05$. Hal ini berarti semua data berdistribusi normal.

Uji Multikolinearitas diketahui bahwa hasil Tolerance 0,862>0,1 atau varian inflation factor (VIF) $1,160<10$. Sehingga dapat dinyatakan bahwa tidak ada multikolinearitas antara konsep diri dan kemampuan kognitif pada analisis regresi ganda ini.

Uji Heteroskedastisitas menunjukkan titik-titik menyebar secara acak dan tidak membentuk pola tertentu yang jelas, serta tersebar di atas maupun di bawah angka 0 pada sumbu Y. Hal ini menunjukkan bahwa tidak terjadi heteroskedastisitas pada model regresi tersebut, sehingga dapat dipakai untuk memprediksi variable minat belajar Bahasa Inggris berdasarkan konsep diri dan kemampuan kognitif.

Uji Normalitas Galat menunjukkan nilai $\mathrm{Z}=0,737$ dan Sig. $=0,649>0,05$. Hal ini berarti asumsi atau persyaratan analisis regresi terpenuhi.

Uji Linearitas menunjukkan Linearitas Regresi pengaruh variable $\mathrm{X}_{1}$ atas $\mathrm{Y}$. Berdasarkan hasil perhiungan, diperoleh hasil perhitungan Deviation from Linearity dengan Fo $=0,409$ dan Sig. $=0,870>0,05$. Hal ini memiliki pengertian bahwa variabel konsep diri dengan minat belajar Bahasa Inggris siswa mempunyai mempunyai hubungan yang linear.
Linaeritas Regresi pengaruh variable $\mathrm{X}_{2}$ atas $\mathrm{Y}$. Berdasarkan hasil perhiungan, diperoleh hasil Deviation from Linearity dengan Fo = 0,698 dan Sig. = 0,652>0,05. Hal ini memiliki pengertian bahwa variabel kemampuan kognitif dengan minat belajar Bahasa Inggris siswa mempunyai mempunyai hubungan yang linear.

Pengujian Hipotesis Pengaruh Konsep diri $\left(\mathrm{X}_{1}\right)$ dan Kemampuan kognitif $\left(\mathrm{X}_{2}\right)$ secara bersama-sama terhadap Minat belajar Bahasa Inggris (Y). Hipotesis yang diuji:

$H_{0}: \beta_{y 1}=\beta_{y 2}=0$

$H_{1}: \beta_{y 1} \neq 0, \beta_{y 2} \neq 0$

Artinya:

$\mathrm{H}_{0}$ : tidak terdapat pengaruh konsep diri dan kemampuan kognitif secara bersama-sama terhadap minat belajar Bahasa Inggris.

$\mathrm{H}_{1}$ : terdapat pengaruh konsep diri dan kemampuan kognitif secara bersama-sama terhadap prestasi belajar bahasa Indonesia. Terdapat pengaruh yang signifikan konsep diri dan kemampuan kognitif secara bersama-sama terhadap minat belajar Bahasa Inggris. Hal ini dibuktikan dengan perolehan nilai Sig. $0,000<0,05$ dan $\mathrm{F}_{\mathrm{h}}=$ 16,385 .

Sementara itu, persamaan garis regresi ganda dapat dinyatakan dengan $\hat{Y}=42,574$ $+0,322 X_{1}+0,359 X_{2}$. Hal ini memiliki pengertian bahwa kenaikan satu skor variable konsep diri dan kemampuan kognitif memberikan kontribusi sebesar 0,322 oleh $\mathrm{X}_{1}$ dan 0,359 oleh $\mathrm{X}_{2}$ terhadap variable minat belajar Bahasa Inggris . Dari tabel 4.9 juga dapat menjelaskan bahwa secara bersama-sama variable konsep diri dan kemampuan kognitif memberikan kontribusi sebesar 31,9\% terhadap variable minat belajar Bahasa Inggris.

Pengaruh Konsep diri $\left(\mathrm{X}_{1}\right)$ terhadap Minat belajar Bahasa Inggris (Y)

Hipotesis yang diuji:

$H_{0}: \beta_{y 1}=0$

$H_{1}: \beta_{y 1} \neq 0$

Artinya:

$\mathrm{H}_{0}$ : tidak terdapat pengaruh konsep diri terhadap minat belajar Bahasa Inggris.

$\mathrm{H}_{1}$ : terdapat pengaruh konsep diri terhadap minat belajar Bahasa Inggris. 
Dapat dinyatakan bahwa terdapat pengaruh yang signifikan konsep diri terhadap minat belajar Bahasa Inggris. Hal ini dibuktikan dengan perolehan nilai Sig. $0,004<0,05$ dan $t_{h}=2,986$.

Adapun kontribusi variabel konsep diri terhadap minat belajar Bahasa Inggris dapat dinyatakan dengan rumus: $\mathrm{KD}=$ Nilai $\beta_{x 1 y}$ $x$ Nilai Korelasi Pasialnya $\left(r_{x 1 y}\right)$ x $100 \%$ $\mathrm{KD}=0,317 \times 0,452 \times 100 \%=14,33 \%$ Dari hasil perhitungan di atas dapat dinyatakan bahwa kontribusi konsep diri dalam meningkatkan minat belajar Bahasa Inggris sebesar $14,33 \%$.

Pengaruh Kemampuan kognitif $\left(\mathrm{X}_{2}\right)$ terhadap Minat belajar Bahasa Inggris (Y) Hipotesis yang diuji:

$H_{0}: \beta_{y 1}=0$

$H_{1}: \beta_{y 1} \neq 0$

Artinya:

$\mathrm{H}_{0}$ : tidak terdapat pengaruh kemampuan kognitif terhadap prestasi belajar bahasa Indonesia.

$\mathrm{H}_{1}$ : terdapat pengaruh kemampuan kognitif terhadap minat belajar Bahasa Inggris.

Dapat dinyatakan bahwa terdapat pengaruh yang signifikan kemampuan kognitif terhadap minat belajar Bahasa Inggris . Hal ini dibuktikan dengan perolehan nilai Sig. $0,001<0,05$ dan $t_{h}=$ 3,425 .

Adapun kontribusi variabel kemampuan kognitif terhadap minat belajar Bahasa Inggris dapat dinyatakan dengan rumus: $\mathrm{KD}=$ Nilai $\beta_{x 2 y} \times$ Nilai Korelasi Pasialnya $\left(r_{x 2 y}\right) \times 100 \%$

$\mathrm{KD}=0,364 \times 0,482 \times 100 \%=17,55 \%$

Dari hasil perhitungan di atas dapat dinyatakan bahwa kontribusi kemampuan kognitif dalam meningkatkan minat belajar Bahasa Inggris sebesar 17,55\%.

Pengaruh pengaruh konsep diri (X1) dan kemampuan kognitif (X2) secara bersama-sama terhadap minat belajar Bahasa Inggris (Y). Hasil penelitian di atas menyimpulkan bahwa konsep diri dan kemampuan kognitif secara bersama-sama telah memberikan pengaruh positif terhadap peningkatan minat belajar Bahasa Inggris siswa SMK Manggala Tangerang. Hal ini mengandung arti bahwa konsep diri dan kemampuan kognitif telah memberikan pengaruh yang signifikan terhadap peningkatan minat belajar Bahasa Inggris siswa SMK Manggala Tangerang.

Pengaruh konsep diri (X1) terhadap minat belajar Bahasa Inggris (Y). Hasil penelitian di atas menyimpulkan bahwa konsep diri telah memberikan pengaruh positif terhadap peningkatan minat belajar Bahasa Inggris SMK Manggala Tangerang. Hal ini mengandung arti bahwa konsep diri, siswa memberikan pengaruh yang cukup signifikan terhadap peningkatan minat belajar Bahasa Inggris siswa SMA Swasta di Kota Tangerang.

Pengaruh Kemampuan kognitif (X2) terhadap Minat belajar Bahasa Inggris (Y). Dari hasil penelitian dan teori yang ada dapat disimpulkan bahwa kemampuan kognitif telah memberikan pengaruh positif terhadap peningkatan minat belajar Bahasa Inggris SMK Manggala Tangerang. Artinya, kemampuan kognitif yang tinggi telah memberikan pengaruh yang signifikan terhadap peningkatan minat belajar Bahasa Inggris siswa SMK Manggala Tangerang.

\section{SIMPULAN}

Terdapat pengaruh yang signifikan konsep diri dan kemampuan kognitif secara bersama-sama terhadap minat belajar Bahasa Inggris siswa SMK Kota Tangerang. Hal ini dibuktikan dengan perolehan nilai Sig. $0,000<0,05$ dan $F_{h}=16,385$. Secara bersama-sama konsep diri dan kemampuan kognitif memberikan kontribusi sebesar $31,9 \%$ terhadap variable minat belajar Bahasa Inggris.

Terdapat pengaruh yang signifikan konsep diri terhadap minat belajar Bahasa Inggris siswa SMK Kota Tangerang. Hal ini dibuktikan dengan perolehan nilai Sig. 0,004 $<0,05$ dan $t_{h}=2,986$. Variabel konsep diri memberikan kontribusi sebesar 14,33\% dalam meningkatkan minat belajar Bahasa Inggris.

Terdapat pengaruh yang signifikan kemampuan kognitif terhadap minat belajar Bahasa Inggris siswa SMK Kota Tangerang. 
Hal ini dibuktikan dengan perolehan nilai Sig. 0,001 $<0,05$ dan $t_{h}=3,425$. Variabel kemampuan kognitif memberikan kontribusi

\section{DAFTAR PUSTAKA}

Abdurahman, Maman dan S.A. Muhidin. 2007. Analisis Korelasi, Regresi, dan Jalur (dilengkapi Aplikasi Program SPSS). Bandung : Pustaka Setia.

Ahmadi, Abu dan Widodo Supriyono. 2008. Psikologi Belajar. Jakarta : PT.Rineka Cipta.

Angkowo.R dan Kosasih.A. 2007. Optimalisasi Media Pembelajaran. Jakarta : Penerbit PT Grasindo.

Arifin, Zaenal. 2009. Evaluasi Pembelajaran. Bandung : PT Remaja Rosdakarya.

Arikunto, Suharsimi. 2006. Dasar-dasar Evaluasi Pendidkan. Jakarta: Bumi Aksara.

Hurlock, Elizabeth B. 1981. Child Development. Tokyo: McGraw Hill Kokagusha Ltd.

Jalaluddin, Rakmat. 2005. Psikologi Komunikasi. Bandung : Remaja Karya. sebesar $17,55 \%$ dalam meningkatkan minat belajar Bahasa Inggris.

Pangabean, Maruli. 2001. Bahasa Pengaruh dan Pernannya. Jakarta : Gramedia.

Pidarta, Made 2004. Manajemen Pendidikan Indonesia. Jakarta : Penerbit Rineka Cipta.

Purwanto, Ngalim. 2010. Psikologi Pendidikan. Cetakan ke 24. Bandung: Remaja Rosdakarya.

Riduan. 2007. Belajar Mudah Penelitian. Bandung : Penerbit Alfabeta.

Sagala, Syaiful. 2007. Administrasi Pendidikan Kontemporer. Bandung : Penerbit Alfabeta.

Santoso, Kusno, 2001. Problematika Bahasa. Bandung : Angkasa.

Slameto. 2003. Belajar dan Faktor-faktor yang Mempengaruhi. Jakarta : PT. Rineka Cipta.

Sudjana, Nana..2007. Penelitian Hasil Proses Belajar Mengajar. Bandung : Remaja Rosdakarya.

Wibowo, Wahyu. 2001. Manajemen Bahasa. Jakarta : Grmedia. 